\title{
YOGYAKARTA DALAM KEPUNGAN IKLAN (Sebuah Kajian tentang Estetika Lingkungan)
}

\author{
Prayanto Widyo Harsanto \\ Desain Komunikasi Visual, Fakultas Seni Rupa \\ Institut Seni Indonesia Yogyakarta \\ prayantowh@ymail.com
}

\begin{abstract}
Banyaknya iklan luar ruang yang memenuhi sudut-sudut kota di Yogyakarta saat ini pada akhirnya menimbulkan berbagai permasalahan. Di Yogyakarta, kini jalan-jalan selain telah dipenuhi lalulintas yang padat, masyarakat pengguna jalan masih dijejali berbagai macam bentuk media iklan luar ruang, sehingga semakin lengkap kesemrawutan lingkungan kota (tata kota) di Yogyakarta. Kondisi yang demikian bisa berujung pada kekhawatiran hilangnya slogan yang dicanangkan pemerintah dan kebanggaan masyarakat Yogyakarta yaitu Jogya istimewa dan Jogya berhati nyaman. Berfokus pada iklan luar ruang yang bertebaran di Yogyakarta, studi ini menyoroti fakta bahwa ada interaksi antara iklan dan konteks lingkungan-sosial.
\end{abstract}

Untuk mendeskripsikan terhadap fenomena penelitian dengan objek material berupa iklan luar ruang di Yogyakarta, maka penelitian menggunakan pendekatan estetika lingkungan-sosial dari Berleant dan Victor Papanek. Dimana estetika lingkungan-sosial adalah estetika kontekstual, berangkat dari karya seni yang terwujud dalam penciptaan karya dan diapresiasi, terkait dengan konteks lingkungan-sosial.

Dalam konteks fungsional, iklan dibuat untuk tujuan membantu pemasaran atas produk dan jasa secara persuasif kepada target audiens. Pada konteks estetis, tampilan/pemasangan iklan luar ruang perlu melihat tata ruang kota yang enak dilihat, tidak merusak pandangan dan tidak menyalahi aturan. Karena citra visual kota sangat terkait dengan terbentuknya identitas sebuah kota, sebuah jati diri yang membuat kota dikenal secara spesifik dan berbeda dengan kota-kota lainnya. Tentu saja, citra visual yang baik yang mampu memberikan identitas yang baik pula, dan di lain sisi, citra kota yang buruk akan memberikan identitas yang buruk pada kota tersebut.

Keywords: Yogyakarta, Outdoor advertisment, Environmental aesthetic

Relevance to Visual Communication Design Practice: Informasi singkat (15-25 kata) mengenai seberapa jauh dan aplikatif hasil penelitian untuk praktik disain komunikasi visual

\section{A. PENDAHULUAN}

Penataan ruang kota dan wilayah merupakan kegiatan menentukan, merencanakan, dan memastikan bagaimana penggunaan ruang secara proporsional sehingga area yang ada dapat memenuhi aspek kegiatan ekonomi, sosial, dan lingkungan hidup. Pada umumnya penataan tata ruang kota dan wilayah tergantung usaha pemegang kebijakan untuk menentukan visi ataupun arah dari kota yang menjadi tanggung jawab pemegang kekuasaan di wilayah. Tata ruang perkotaan tidak hanya tampak fisik dari lingkungan saja tetapi juga mempengaruhi pengakuan identitas, baik individual atau kolektif.

Fenomena dan permasalahan tata kota tersebut menjadi wacana serius di Yogyakarta, dalam dasa warsa terakhir ini menghadapi permasalahan dilematis dengan maraknya pembangunan berbagai hotel dan pusat perbelanjaan di seluruh penjuru kota, masih ditambah dengan banyaknya iklan luar 
ruang yang bertebaran di setiap ruas jalan dan di sudut-sudut jalan seperti spanduk, baliho, banner, poster, sign system, dan lain sebagainya. Di satu sisi fenomena tersebut telah mendorong pertumbuhan investasi daerah, namun di sisi lain dinilai telah menggerus kenyamanan hidup masyarakat kota Yogyakarta. Kondisi yang demikian bisa berujung pada kekhawatiran hilangnya slogan yang dicanangkan pemerintah dan kebanggaan masyarakat Yogyakarta yaitu Jogya istimewa dan Jogya berhati nyaman.

Yogyakarta dengan sederet predikat seperti kota pelajar, kota budaya, kota perjuangan, kota wisata, kota gudeg, dan predikat lainnya. Berbagai predikat atau sebutan tersebut merupakan kebanggaan bagi warga Yogyakarta, akan tetapi juga menjadi tanggung jawab yang tidak ringan yang harus dipikul bersama. Persoalan yang ada di Yogyakarta tidak jauh berbeda dengan kotakota besar di Indonesia saat ini, seperti persoalan kemacetan, kejahatan, kependudukan, kesemrawutan tata kota dll. Salah satu persoalan tersebut adalah keberadaan iklan luar ruang yang bertebaran, semrawut, dan merusak keindahan kota Yogyakarta yang berslogan "Jogja Berhati Nyaman" dan " Jogya Istimewa”. Benarkah Yogyakarta saat ini sesuai dengan slogannya? Bagaimana dengan banyaknya iklan luar ruang yang bertebaran di setiap ruas jalan dan di sudut-sudut jalan seperti spanduk, baliho, poster, sign system, dan bentuk iklan yang lain?

Keadaan iklan luar ruang di Yogyakarta menurut Laretna T. Adhisakti (dosen Arsitektur/Fakultas Teknik UGM) dalam sarasehan di Kepatihan Yogyakarta, menilai kondisi iklan luar ruang di DIY sudah gawat darurat. Tak hanya soal pemasangan iklan yang tidak pada tempatnya, tetapi juga jumlah papan reklame yang sangat banyak. Sementara berdasarkan data Badan Periklanan Daerah Persatuan Perusahaan Periklanan Indonesia (P3I) DIY, jumlah iklan yang dipasang kurun Januari 2013-Oktober 2013 di Kota Yogyakarta 1.329 unit. Jika papan iklan dipajang di tepi jalan kota yang panjangnya 32 meter secara berderet panjangnya 28 kilometer. Artinya, kepadatan iklan 87,5 persen. "Itu yang membuat tidak nyaman publik," kata Ketua Badan Periklanan Daerah P3I DIY Fransisca Anita Herawati.

Melihat permasalahan iklan luar ruang yang bertebaran dan mengepung Yogyakarta tersebut pihak Pemda DIY telah membahas melalui Rancangan Peraturan Daerah tentang Iklan Luar Ruang, yaitu tentang larangan memasang di lokasi tertentu. Lokasi itu meliputi taman kota, ruang terbuka hijau, trotoar, dinding bangunan warisan budaya, jembatan, tiang telepon, listrik, rambu lalu lintas, lampu penerangan jalan, dan pohon, serta penataan dan pembatasan jumlah videotron. Upaya lain yang juga dilakukan adalah gerakan reresik sampah visual yang digagas oleh Sumbo Tinarbuko (Dosen ISI Yogyakarta) bersama elemen masyarakat pada tahun 2012 yang hingga kini masih berlangsung. Namun, berbagai usaha dan upaya tersebut tidak menghasilkan Jogya yang berhati nyaman sesuai harapan semua pihak secara signifikan. Hal ini bisa dilihat di setiap sudut perempatan/pertigaan poster, billboard semakin banyak terpasang. Demikian pula di sepanjang jalan protokol juga masih banyak terlihat pemandangan berbagai jenis dan bentuk iklan luar ruang seperti spanduk, 
poster, umbul-umbul, dan banner yang dipasang tidak pada tempatnya.

\section{B. PERMASALAHAN IKLAN LUAR RUANG DI YOGYAKARTA}

Secara konseptual permasalahan tentang desain iklan tidak bisa mutlak diselesaikan dengan sebuah ilmu secara tunggal dan absolut, artinya dalam praktik kerjanya iklan banyak diwarnai berbagai permasalahan (advertising is based on a problem). Di dalamnya terdapat berbagai kepentingan, seperti kepentingan ekonomi, sosial, budaya, politik, teknologi, komunikasi, maupun seni rupa (Davidson, 1992: 148 dan Frascara, 2004: 43).

Selama ini ada kecenderungan penilaian sebagian masyarakat yang melihat iklan terutama sebagai sebuah karya visual yang bertujuan membujuk orang untuk membeli produk. Wacana iklan sebagian besar dibangun di sekitar gagasan untuk menciptakan strategi penjualan yang efektif, yang dapat memotivasi dan membujuk orang untuk membeli produk yang ditawarkan. Karya iklan merupakan hasil dari perpaduan berbagai displin ilmu (seni, komunikasi, psikologi, sosialogi, ekonomi) yang bercampur menjadi satu sehingga menjadi suatu kesatuan yang harmonis. Artinya bahwa karya iklan diproduksi selain bertujuan menjual/menawarkan produk yang berhubungan dengan konteks sosial-budaya tetapi juga senantiasa mempertimbangkan aspek estetika.

Fakta dari masalah ini adalah bahwa iklan merupakan alat persuasi yang ampuh untuk mempengaruhi dan menjual produk. Hal ini menunjukkan bahwa iklan diproduksi tidak dalam ruang kosong dan tidak dapat dipisahkan dari praktik-praktik budaya sehari-hari. Iklan senantiasa terkait dengan tatanan sosio-budaya dan politik yang lebih besar dan lebih luas pada momen historis tertentu dalam suatu masyarakat tertentu. Iklan merupakan salah satu alat pendorong gaya hidup melalui nilai-nilai estetika yang dibangun bersama unsur lain (Frascara, 2004: 18). Momentum pertumbuhan ekonomi dan perkembangan infrastruktur di pasca Orde Baru menciptakan peningkatan strata sosial dan hal ini menjadi target pemasaran bagi produk-produk yang diiklankan.

Berfokus pada iklan luar ruang yang bertebaran di Jogja, studi ini menyoroti fakta bahwa ada interaksi antara iklan dan konteks lingkungan-sosial di mana teks muncul. Penulis berpendapat bahwa iklan luar ruang di Jogja memerlukan penataan ulang dan pemahaman tertentu dalam mempertimbangkan estetika tata ruang agar Yogyakarta betul-betul sesuai slogannya yaitu "Jogya berhati nyaman" dan "Jogya istimewa". Tampilan iklan luar ruang yang telah mengepung Yogyakarta dalam pandangan penulis telah membuka celah untuk mengabadikan wacana estetika, sosial, dan politik ekonomi dalam tahun-tahun terakhir ini. Fenomena yang terjadi tersebut tidak hanya pada fenomena visual saja, tetapi juga secara kontekstual. Dalam hal ini iklan juga memberikan arti secara konteks fungsional maupun konteks estetis. Dalam konteks fungsional, iklan dibuat untuk tujuan membantu pemasaran atas produk dan jasa secara persuasif kepada target audiens. Pada konteks estetis, tampilan/pemasangan iklan luar ruang perlu melihat tata ruang kota yang enak dilihat, tidak merusak pandangan dan tidak menyalahi aturan. Hal ini menjadi 
contoh yang sangat baik untuk mengeksplorasi keterkaitan antara media iklan luar ruang dan sosial, ekonomi, budaya, dan kepentingan politik di Yogyakarta.

Sebagaimana latar belakang masalah yang dipaparkan di muka, maka penelitian ini mencakup permasalahan iklan luar ruang yang bertebaran di Yogyakarta dalam satu tahun terakhir ini. Untuk itu, yang menjadi pertanyaan adalah bagaimana kondisi lingkungan tata kota Yogyakarta sehingga bisa seperti ini? Bagaimana peran pemerintah dalam melihat dan menyikapi kondisi ini? Apakah ada permasalahan politik ekonomi serta sosial budaya saling mempengaruhi, sehingga harus mengabaikan keindahan tata kota?

Bertolak dari pertanyaan-pertanyaan tersebut, maka penelitian ini dilakukan dan bertujuan untuk mengetahui fenomena visual iklan luar ruang yang bertebaran di Yogyakarta. Penelitian ini dilakukan juga untuk mendapatkan konsep tata ruang publik terkait penempatan iklan. Selain itu, juga untuk mengetahui seberapa besar kebijakan pemda berpengaruh terhadap ijin pemasangan iklan.

\section{METODE/PENDEKATAN}

Untuk mendeskripsikan secara mendalam terhadap fenomena penelitian dengan objek material berupa iklan luar ruang di Yogyakarta, maka penelitian menggunakan pendekatan estetika lingkungan. Estetika adalah ilmu tentang pengalaman inderawi, sebagaimana yang disampaikan Alexander Baumgarten (1714-1762), Estetika diletakkan di wilayah nilai, terkait indah dan tidak indah, selera, rasa suka dan tidak suka. Pengalaman inderawi tidak hanya berhadapan dengan karya seni dan alam, tetapi dengan seluruh aspek kehidupan sehari-hari. Gagasangagasan tersebut telah melahirkan pemikiran tentang estetika lingkungan-sosial, karena pengalaman individu berhadapan dengan pengalaman individu lain, bahkan dengan lingkungan masyarakat (Berleant, 2010).

Estetika lingkungan-sosial adalah estetika kontekstual, berangkat dari karya seni yang terwujud dalam penciptaan karya dan diapresiasi, terkait dengan konteks lingkungan-sosial. Yang dimaksud karya seni dalam kajian ini tidak lain karya desain iklan. Iklan luar ruang dalam hal ini menjadi variabel penting sebab melalui iklan luar ruang yang berfungsi menyampaikan pesan menentukan seperti apa bentuk, jenis, dan tempat pemasangan di mana seseorang/masyarakat diharapkan atau dipaksa untuk melihat.

Untuk menganalisis teks dan mengevaluasi materi visual digunakan metode penelitian visual dengan object based approach. Artinya karya visual sebagaimana iklan luar ruang sebagai dasar amatan dalam penelitian. Untuk menganalisis suatu karya visual, secara umum terdapat tahapan mendasar yang merupakan susunan yang direncanakan secara jelas untuk menghindarkan tanggapan tentang senang atau tidak senang terhadap suatu karya. Menurut Feldman (1992:487), menganalisis karya visual dapat dibagi dalam tahapantahapan yang mendasar, yaitu 1) Deskripsi (Description), 2) Analisis (Analysis), 3) Penilaian (Judgement), dan 4) Kesimpulan (Conclusion) merupakan pendapat akhir yang berisi informasi yang berdasarkan fakta dan alasan dari hasil suatu objek penelitian. Kemudian tahap berikutnya adalah analisis 
kontekstual. Analisis kontekstual merupakan analisis wacana dengan bertumpu pada teks yang dikaji berdasarkan konteks eksternal yang melingkupinya, baik konteks situasi maupun konteks kultural. Sementara untuk memperoleh data dalam kajian ini ditempuh langkah-langkah pengumpulan data yang meliputi: dokumentasi, observasi, dan kepustakaan.

\section{a. Metode Dokumentasi}

Dokumentasi dilakukan melalui pencatatan dan pemotretan iklan luar ruang yang diperoleh di berbagai jalan protokol, perempatan, pertigaan jalan di wilayah kota Yogyakarta. Di tempat ini seluruh bentuk, jenis iklan luar ruang bisa ditemukan, dengan demikian iklan luar ruang tersebut dapat dilihat dan ditelusuri sehingga diperoleh informasi serta data-data yang akurat dan lengkap.

\section{b. Metode Observasi}

Langkah-langkah yang dikerjakan dalam melakukan observasi atau pengamatan adalah mencermati kelompok inti pada iklan luar ruang yang menggunakan unsur ilustrasi. Dengan demikian, observasi terfokus dengan mencurahkan perhatian secara penuh pada iklan display (baliho). Pada umumnya iklan display (baliho) terdapat di sudut-sudut perempatan, pertigaan atau tikungan jalan protokol. Tujuan utama observasi pada umumnya adalah untuk konteks "penemuan". Tujuan observasi dalam penelitian ini adalah untuk mendapatkan gambaran tentang tempat/titik pasang, pesan iklan, produk yang ditawarkan.

\section{c. Kepustakaan}

Kepustakaan digunakan untuk membantu dalam penyusunan dan penulisan kajian ini. Secara garis besar sumber bacaan (kepustakaan) dibedakan menjadi: Sumber bacaan umum, berbentuk buku; Sumber acuan yang lain seperti majalah, koran, dan internet.

\section{PEMBAHASAN}

\section{Iklan Luar Ruang Sebagai media Promosi}

Yogyakarta sebagai salah satu propinsi di Indonesia sudah dikenal sebagai wilayah yang berkembang dan ramai oleh pendatang, baik wisatawan maupun para pelajar. Sebab kota Yogyakarta dianggap sebagai salah satu kota tujuan pendidikan. Selain itu, unsur-unsur budaya dan keramahtamahan yang masih kental juga menjadikan kota Yogyakarta tetap sebagai salah satu kota yang menarik untuk dikunjungi. Hal tersebut tentu merupakan sasaran yang memiliki potensi dalam melaksanakan promosi, khususnya melalui media iklan. Untuk keberhasilan dalam memasarkan berbagai macam produk, baik berupa barang maupun jasa yang melimpah media iklan menjadi salah satu sarana yang penting sebagai media komunikasi pemasaran.

Salah satu media iklan tersebut adalah media luar ruang. Media iklan luar ruang (ILR) merupakan salah satu media promosi yang diletakkan di luar ruangan yang memiliki tujuan untuk menyampaikan pesan suatu produk atau jasa. Menurut Khasali (1999), media iklan luar ruang adalah media yang dipasang di tempat-tempat terbuka seperti di pinggir jalan, di pusat keramaian atau tempat-tempat khusus lain, seperti di dalam bus kota, gedung, pagar tembok, dan 
sebagainya. Keberadaan media iklan luar ruang tidak lain pemanfaatan ruang publik sebagai sarana komersial untuk mengenalkan suatu produk pada khlayak. Pertimbangan lokasi penempatan iklan media luar ruang menjadi hal yang sangat penting, lokasi yang paling diminati adalah titik yang banyak dilewati orang. Sementara keunggulan iklan luar ruang, adalah sebagai berikut.

1. Jangkauannya luas, di mana pesan dapat disampaikan ke semua segmen masyarakat.

2. Durasi penayangan yang lebih lama dari media lainnya, dapat mencapai hitungan bulanan bahkan tahunan.

3. Tidak ada biaya langsung yang ditanggung oleh konsumen.

4. Mempunyai potensi untuk menarik perhatian melalui ukuran, bentuk dan warna media yang mencolok.

5. Adanya efek pengulangan pesan yang berkali-kali setiap melihatnya.

Meskipun media iklan luar ruang memiliki berbagai keunggulan, tetapi juga ada kekurangannya, yaitu:

1. Iklan luar ruang lebih berfungsi sebagai pengingat produk, sementara fungsi untuk menjelaskan produk biasanya lebih mengunakan media cetak maupun elektronik.

2. Sasaran iklan luar ruang tidak selektif dan tidak fokus, sehingga sulit mengukur keberhasilan penyampaian pesan.

3. Waktu terpaan pesan yang relatif terbatas, karena biasanya sasaran melihat iklan luar ruang secara sekilas, dan pemasangan iklan media luar ruang sering pula mengganggu fungsi fasilitas umum.
Menurut Khasali (1995:13), salah satu syarat utama iklan luar ruang haruslah menarik, atau eye catching. Iklan luar ruang sebisa mungkin dapat dipandang lama, yang berarti dari jarak yang cukup jauh sudah dapat dilihat. Iklan luar ruang dinilai memiliki fleksibilitas yang cukup tinggi karena tidak terbatas pada durasi, titik penempatannya elastis, dan memiliki daya tangkap yang tinggi. Sebagai upaya kreatif pemasangan iklan luar ruang pada umumnya menyatu dengan fasilitas publik, seperti lampu jalan, elamen estetika kota, jembatan penyebrangan, halte bus, telepon umum, bus surat, tempat sampah. Iklan luar ruang (ILR) selain mengganggu kenyamanan atau secara psikologis menjadi teror visual bagi masyarakat Yogyakarta, secara tidak langsung juga berdampak menggugah orang untuk bergaya hidup konsumtif. Karena iklan luar ruang rata-rata menawarkan produk berupa barang dan jasa.

Sebuah image dalam iklan tidak sekadar berfungsi sebagai informasi visual tentang produk atau pelbagai kebutuhan konsumsi, tetapi dengan kemampuannya membangun citra melalui tanda, idiom, simbol dan kode produk komoditas. Sehubungan dengan teori periklanan, Hurlburt dalam The Design Concept (1981: 22-29) mengungkapkan bahwa ada tiga konstruksi penting dalam iklan yakni: Informasi, Identifikasi, dan Persuasi. Hal ini bisa dijelaskan bahwa pada dasarnya setiap iklan senantiasa memiliki fungsi sebagai media untuk menyampaikan informasi. Fungsi memberitahukan, menginformasikan sesuatu hal berkaitan dengan produk dan jasa kepada konsumen merupakan misi utama dalam iklan. Apa yang diinformasikan dalam iklan mengandung 
maksud mempengaruhi atau membujuk konsumen dengan sajian tertentu supaya dapat menimbulkan rangsang yang mengarah kepada sikap dan perilaku tertentu. Di sini dapat dikatakan bahwa "iklan adalah persuasi" karena hampir semua penyajian iklan mengandung maksud mempengaruhi atau membujuk khalayak dengan sajian tertentu supaya dapat menimbulkan rangsang yang mengarah kepada sikap dan perilaku sesuai yang diharapkan oleh iklan. Paparan tersebut dapat dilihat bahwa antara fungsi informasi, identifikasi, dan persuasi memiliki hubungan yang saling terkait dan tidak terpisahkan.

Dalam hal ini iklan luar ruang sebagaimana yang bertebaran di kota Yogyakarta digunakan sebagai medium komunikasi pemasaran untuk menawarkan produk dan menanamkan ideologi (gaya hidup) kepada calon konsumen. Salah satunya dengan terjadinya perubahan sosial dan gaya hidup di Yogyakarta banyak didorong oleh rangsangan pesan iklan luar ruang. Selaras dengan apa yang dikatakan Jean Baudrillard (2006: 156) bahwa dasardasar fungsi komoditas tidak lagi ditentukan dengan adanya nilai guna atau nilai tukar semata, melainkan juga ditentukan oleh nilainilai simbol dan tanda yang dilekatkan pada komoditas-komoditas tersebut. Oleh karena itu, komoditas atau obyek-obyek konsumsi menjelma menjadi sebuah sistem klasifikasi masyarakat, status, prestise, dan pola tingkah laku masyarakat. Tema-tema gaya hidup, kelas, kemewahan, adalah bentuk idiologi tanda dan simbol konsumsi yang dimasukkan ke dalam komoditas. Modus konsumsi inilah yang akhirnya mengubah seluruh aspek kehidupan menjadi obyek konsumsi yang berupa komoditi.

Berikutnya adalah karya Stuart Ewen (2001) berjudul "Captains Of Consciousness Advertising and The Social Roots Of The Consumer Culture". Menurut Stuart Ewen, iklan sebagai captain of industry bertujuan mengamankan bagian pasar dengan cara mengorganisir dan mengontrol selera dan perilaku masyarakat. Situasi melimpahnya barang konsumsi di pasar menurut Stuart Ewen disebut sebagai a continually responsive consumer marketing. Dalam hal ini terjadi pergeseran, di mana konsumen yang semula mencari barang dengan kualitas yang bisa dipercaya, kini pabrik barang-baranglah yang mencari konsumen. Pabrik tidak hanya memproduksi barang tetapi juga harus memproduksi konsumen yang akan membeli barang tersebut. Dalam hal ini iklan menjadi sarana utama, di mana iklan bertugas menciptakan hasrat dalam diri konsumen, mengingatkan konsumen bahwa ada yang kurang dalam hubungan mereka dengan orang lain, menawarkan dan menyarankan penggunaan produknya sebagai jawaban atau solusinya.

\section{ILR dan Estetika Tata Kota}

Maraknya Iklan Luar Ruang (ILR) di setiap sudut kota Yogyakarta bila tanpa diimbangi pelaksanaan aturan dari pemerintah setempat, baik dilihat dari segi desain, dimensi, maupun letak pemasangannya membuat kota Yogyakarta tampak semrawut. Pemandangan ini dapat ditemukan di hampir sepanjang jalan protokol di Yogyakarta. Belum lagi, kondisi ini diperburuk ketika masuk musim Pilkada dan kampanye partai politik serta calegnya. Hampir di setiap sudut 
jalan di kota Yogyakarta dapat ditemukan iklan luar ruang seperti baliho, poster, spanduk, banner, dan berbagai media iklan luar ruang lainnya dengan berbagai ukuran yang terpajang secara sembarang. Ditambah lagi tidak adanya tindakan dari pemerintah untuk mencopot media iklan luar ruang yang sudah melebihi batas akhir pemasangan, sehingga menjadi sampah visual yang kian memperburuk citra kota Yogyakarta.

Kesemrawutan ILR di Yogyakarta ikut memperburuk estetika tata kota yang berslogan "Jogya berhati nyaman". Menurut A.A.M Djelentik (1999:10-12), estetika kota tidak lain adalah estetika tentang (per) kota (an), yang dibentuk oleh struktur, tata ruang, ornamen dan termasuk keindahan, kerapian, dan kebersihan kota. Berdasarkan konsep tersebut, iklan luar ruang berupa poster, billboard, spanduk, balon udara, videotron, dan neon box yang berada di pinggir jalan, media jalan, taman kota, pohon, tiang listrik dan gedung di sekitar kota Yogyakarta dilihat dari segi estetika kota banyak yang tidak mencerminkan estetika kota. Sebab banyak media iklan luar tersebut yang dipasang pada tempat-tempat tertentu yang mengganggu keindahan sebuah kota.

Estetika, secara umum selama ini dimengerti sebagai studi tentang keindahan. estetika kota atau estetika tentang (per) kota (an) ini merupakan estetika atas lingkungansosial. Estetika yang terwujud dalam penciptaan karya dan apresiasi karya, terkait dengan konteks sosial. Estetika tata kota terkait lingkungan hidup manusia, baik alam maupun sosial. Dan perhatian ini melahirkan kepedulian terhadap suatu hal atau objek, baik itu positif maupun negatif, di mana manusia terikat dengan lingkungannya.
Berleant (2010) menyatakan pengalaman inderawi tidaklah selalu bersifat positif, dan jika itu melukai hati, menyakitkan, mempunyai efek yang jahat dan merusak, pengalaman estetik ini membawa pada wilayah negatif. Nilai estetik juga dapat tampil secara tidak memuaskan, menyakitkan, jahat bahkan menghancurkan. Kepekaan inderawiah diliputi dengan nilai negatif. Perhatian melahirkan kepedulian terhadap suatu hal atau objek. Kepedulian lebih sering dikaitkan dengan etika daripada estetika. Kepedulian melibatkan perhatian, simpati dan empati serta tindakan tertentu yang terkait dengan perilaku moral. Tidak terlalu banyak orang yang memberikan perhatian pada proses bagaimana hingga orang menjadi peduli. Kepedulian berawal dari sense (estetik) yang dimulai dari indera penglihatan, yang akan membentuk sensitivity dan sensibility.

Sebagaimana keberadaan media iklan luar ruang di Yogyakarta tidak lebih dari sampah visual yang mengganggu lingkungansosial bagi masyarakat yang berada di kota Yogyakarta. Satu dasawarsa terakhir, wajah Yogyakarta menjadi semrawut dengan media iklan luar-ruang, yakni reklame di pinggir, pojok, maupun tengah jalan. Beberapa titik keramaian seperti di wilayah Sleman, Yogyakarta yang menjadi sasaran penempatan media luar ruang adalah Jalan Gejayan yang saat ini dikenal dengan nama Jalan Affandi, Jalan Kolombo, perempatan ringroad Condongcatur dilihat dari sudut pandang pengiklan daerah ini merupakan daerah yang berpotensi untuk pemasangan iklan. Daerah ini dinilai sebagai titik pusat yang sering dilalui oleh target audiens. Informasi yang ditawarkan oleh pengiklan yang tentu saja telah dikemas dengan menarik 
akan cepat diserap oleh audiens. Demikian pula sebaliknya, audiens secara sadar maupun tidak telah menerima informasi produk yang diharapkan akan terjadi sikap sesuai yang diinginkan oleh pengiklan.

Banyaknya pemasangan iklan di daerah ini menimbulkan kesemrawutan atau menimbulkan sampah-sampah visual bagi masyarakat atau pengguna jalan. Banyaknya iklan luar ruang yang terkadang tidak tertata dengan rapi membuat keindahan jalan, khususnya tata kota menjadi kurang menarik. Dampak itu berimbas pada berkurangnya kenyamanan pengguna jalan yang melalui jalan.

Berdasar dari penjabaran di atas akan muncul permasalahan yang berkaitan dengan penempatan iklan pada media luar ruang di kota Yogyakarta. Permasalahan yang muncul antara lain adalah mengenai tata kota yang semakin terlihat semrawut karena banyaknya gangguan visual berupa iklan luar ruang yang diletakkan di sepanjang jalan-jalan protokol.

Keberadaan iklan luar ruang di Yogyakarta tidak terlepas dari penataan tatakota di Yogyakarta. Peran pemerintah daerah tidak bisa dilepaskan begitu saja dengan permasalahan ini. Sebab, penataan iklan luar ruang di Yogyakarta bisa dikatakan sudah memasuki fase darurat. Hal ini di karenakan iklan luar ruang yang ada sudah melanggar dua aspek penting yang seharusnya diperhatikan Pemerintah Daerah dan pemasang iklan, yakni keindahan dan keselamatan. Terkait soal keindahan, seperti yang kita ketahui sekarang bahwa di setiap sudut kota Yogya kini terdapat reklame yang sebenarnya mengurangi keindahan kota. Wajah kota menjadi tak tampak karena ditutup billboard besar dan tidak beraturan.
Pemerintah beranggapan penempatan iklan luar ruang akan menambah pendapatan daerah dari pajak iklan yang masuk. Pajak dari iklan dikenal sebagai pajak dengan nilai rupiah yang tinggi. Hal tersebut membuat pemerintah daerah cenderung menerima iklan-iklan luar ruang yang dipasang di wilayahnya untuk menunjang kepentingan ekonomi pemerintah. Namun terkadang penempatan iklan luar ruang membuat pemerintah mengesampingkan sisi keindahan kota.

Perlu diketahui bahwa tarif pajak iklan luar ruang yang dipungut saat ini bervariasi tergantung dari ukuran dan jenis iklan yang ditampilkan. Pemerintah Kota (Pemkot) Yogyakarta berencana menaikkan tarif pajak iklan luar ruang menyusul berkurangnya potensi pendapatan dari papan iklan akibat pemberlakukan Peraturan Daerah. Jenis iklan terbagi tiga, yakni iklan rokok yang paling mahal, non rokok, dan yang termurah produk usaha. Ukuran $4 \times 8$ meter untuk iklan rokok mencapai Rp50 juta per tahun, sementara yang non rokok hanya Rp15 juta per tahun. Pada tahun ini ditargetkan pendapatan pajak iklan luar ruang sebesar realisasi 2014, yakni sekitar Rp5,6 miliar. Target ini ditetapkan berkaca dari pendapatan pajak reklame tahun lalu yang hanya mencapai 66\% target (Harian Jogja, Sabtu, 22 Agustus 2014).

Pada umumnya, dalam perencanaan tatakota dan lingkungan masyarakat sering tidak dilibatkan. Mereka memang diberi tempat untuk aktivitas kehidupan, kerja, rekreasi, belanja dan bermukim, akan tetapi kurang diberi peluang untuk ikut dalam proses penentuan kebijakan dan perencanaan. Padahal, bila penduduk/masyarakat kota tidak dilibatkan dalam proses perencanaan 
dan pembangunan kotanya, tidak diberi kesempatan untuk bertindak secara aktif pada lingkungannya, tidak memperoleh peluang untuk membantu, menambah, merubah, menyempurnakan lingkungannya, maka masyarakat kota bisa menjadi apatis, acuh tak acuh, dan mungkin agresif.

Pelibatan masyarakat dalam perencanaan tata kota di Indonesia masih sering diabaikan, padahal penting sekali untuk menumbuhkan kepedulian terhadap wilayahnya. Sebagaimana yang dilakukan komunitas reresik kota Yogyakarta yang dipelopori Sumbo Tinarbuko sebagai salah satu kepedulian akan lingkungan kota Yogyakarta yang lebih nyaman dan tertata dalam masalah iklan luar ruang. Kepedulian masyarakat Yogyakarta akan ILR sangat tinggi sebagaimana diungkapkan penggagas Gerakan Reresik Sampah Visual Yogyakarta. Disebutkan, Sampah visual yang bertebaran di sepanjang jalan berupa papan-papan iklan komersial ataupun kampanye partai ini yang bikin Yogyakarta tak lagi istimewa. Biarkan ruang publik itu milik publik. Jangan jadi milik merek dagang dan partai politik. Ruang publik seharusnya menjadi milik publik, bukan diprivatisasi menjadi milik merek dagang atau partai politik. Keberadaan iklan luar ruang yang berupa produk barang dan jasa serta partai politik harus diatur sesuai dengan peruntukannya, jika tidak keberadaan iklan luar ruang mengganggu keindahan lingkungan.

Memang, sebaiknya peran serta masyarakat dalam proses perencanaan tata ruang dan lingkungan perlu dibuka lebar dan disambut baik oleh Pemda, agar keberadaan iklan luar ruang dapat tertata dengan baik, sehingga bisa memberikan kenyamanan bagi warga kota Yogyakarta. Dengan melihat iklan luar ruang yang disebabkan penataannya yang kurang tepat antara yang satu iklan, saling tumpang tindih, dan jaraknya sangat dekat dilihat terasa tidak nyaman, maka saat ini masyarakat khususnya pengguna jalan menghendaki adanya penataan iklan luar ruang. Masyarakat merasa mulai terganggu dan tidak nyaman dengan adanya intensitas iklan yang banyak dan menimbulkan kesemrawutan. Sikap yang kemudian muncul adalah keinginan masyarakat agar pemerintah melakukan penataan ulang iklan-iklan luar ruang di kota Yogyakarta. Jangan sampai masyarakat menilai sepertinya kepentingan ekonomi mendominasi sehingga menyebabkan kepentingan pengguna jalan atau kepentingan publik menjadi dikesampingkan.

\section{E. KESIMPULAN}

Bagi seorang pengiklan Yogyakarta dipandang sebagai tempat yang strategis dalam melakukan kegiatan periklanan dilihat dari banyak faktor seperti psikografis, geografis, maupun demografisnya. Hal tersebut mengakibatkan banyak sekali iklan dari berbagai produk maupun perusahaan yang ditempatkan di wilayah Yogyakarta khususnya pada media luar ruang. Media ini dianggap efektif untuk menarik perhatian dan memberikan informasi tentang produk yang ditawarkan kepada calon konsumen yang melewati jalan di mana iklan tersebut ditempatkan. Memang, salah satu syarat utama iklan luar ruang haruslah menarik, atau eye catching. Iklan luar ruang sebisa mungkin dapat dipandang lama, yang berarti dari jarak yang cukup jauh sudah dapat dilihat. 
Sebagai kota budaya dan menyandang predikat istimewa sudah seharusnya Yogyakarta memiliki dewan kurator yang bertugas mendampingi dan memandu Pemkot Yogyakarta menata iklan luar ruang agar selaras dengan budaya Yogyakarta. Pada faktanya penempatan iklan luar ruang di kota Yogyakarta cenderung berantakan, dan mengganggu keindahan kota. Iklan luar ruang idealnya dalam ukuran yang sama dan jarak penempatan iklan harus dijaga agar berkesinambungan satu sama lain.

\section{F. PUSTAKA}

[1] Berleant, Arnold, Sensibility and Sense, The Aesthetic Transformation the of Human World, Imprint Academic, 2010

[2] Baudrilard, Jean P (1970) La Societe de Consommation atau Masyarakat Konsumsi, terjemahan Wahyunto, (2006), Kreasi Wacana, Yogyakarta

[3] ---------, (1976), For a Critique of The Political Economy of the Sign, Telos press, St. Louis, MO

[4] Djelantik, A.A.M. 1999. Estetika Sebuah Pengantar. Bandung: Masyarakat Seni Pertunjukan Indonesia.

[5] Davidson, Martin (1994), The Consumerist Manifesto Advertising in Postmodern Times, Routledge, London and New York

[6] Featherstone, Mike (2001), Consumer Culture and Posmornism atau Posmodernisme dan Budaya Konsumen, terjemahan Misbah ZE. (2008) Pustaka Pelajar, Yogyakarta

[7] Feldman, Edmund (1992), Varietas of Visual Experience, Prentice Hall, New York.

[8] Jefkins, Frank (1996), Periklanan (edisi ketiga), Penerbit Erlangga, Jakarta

[9] Holtje, Herbert F. (1978), Theory and Problems of Advertising, Mc, Graw Hill Book Company, USA
[10] Hulburt, Allen (1981), The Design Concept, Watson-Guptill Publications, New York.

[11] Khasali, Renald. (1995), Manajemen Periklanan, PT Pustaka Utama Grafiti, Jakarta.

[12] -------------, (1999), Membidik Pasar Indonesia Segmentasi, Targeting, Positioning, PT Gramedia Pustaka Utama, Jakarta

[13] Papanek, Victor (1984), Design For The Real World: Human Ecology and Social Change, Design Page, Chicago.

[14] Stuart Ewen (2001) berjudul "Captains Of Consciousness Advertising and The Social Roots Of The Consumer Culture".

Sabandar, Penataan reklame Atasi Penurunan Pendapatan, Pemkot Naikkan Tarif Pajak, Harian Jogja, Sabtu, 22 Agustus 2014 